\title{
Perencanaan Pengembangan Sentra Industri (Agrotechnopark Gula Aren) Kabupaten Landak
}

\author{
Fitri Imansyah \\ Jurusan Teknik Elektro, Fakultas Teknik, \\ Universitas Tanjungpura, Pontianak, Indonesia
}

Corresponding Author: Fitri Imansyah, fitri.imansyah@ee.untan.ac.id

\begin{abstract}
Abstrak: Berdasarkan hasil produksi tanaman aren di Kabupaten Landak, maka komoditas ini dinyatakan sebagai komoditas yang dapat diunggulkan bagi peningkatan perekonomian masyarakat setempat. Salah satu daerah penghasil komoditas aren adalah di Desa Kumpang Tengah Kecamatan Sebangki. Kabupaten Landak merupakan wilayah yang memiliki potensi sumber daya alam (SDA) yang memadai untuk suatu pembangunan kawasan agrotechnopark. Produk unggulan merupakan produk yang potensial dikembangkan pada suatu wilayah dengan memanfaatkan SDA dan Sumber daya manusia (SDM) lokal yang berorientasi pasar dan ramah lingkungan sehingga dapat memiliki keunggulan kompetitif dan siap menghadapi persaingan global. Pengembangan Sentra Industri Kecil dan Menengah (IKM) dilakukan melalui perencanaan pengembangan sentra IKM gula aren yang terpetakan secara spasial dan penyediaan rumusan kebijakan kegiatan pengembangan sentra IKM berdasarkan kondisi saat ini. Produk unggulan sentra IKM di kabupaten Landak ini akan ditentukan melalui skoring dengan lima parameter: kebijakan terkait, nilai tambah (harga jual), ketahanan produk, daya saing, dan kemudahan dalam pengolahan. Selain memiliki potensi sumber daya alam pertanian berupa padi, aren, dan tanaman perkebunan lainnya, kabupaten Landak juga memiliki lahan yang masih luas yang memang diperuntukkan untuk kawasan peruntukan pertanian tanaman pangan.
\end{abstract}

Kata Kunci: Sentra industri, agrotechnopark, IKM, gula aren.

Abstract: Based on the production of sugar palm plants in Landak Regency, it is one of commodities that can improve the economy of the local community. One of location that produces palm commodity is in Kumpang Tengah Village, Sebangki District, in Landak. Landak Regency is an area that has potency of natural resource potential for an agrotechnopark area development. Superior products are the potential products to be developed in an area by utilizing local natural resources and human resources based on market orientation and environmentally friendly aspect so that they can have a competitive advantage and are ready to face global competition. The development of Small and Medium Industry Centers (IKM) is carried out through planning the development of palm sugar IKM centers that are spatially mapped and the provision of policy formulations for IKM center development activities based on current conditions. The superior products of the IKM center in Landak district will be determined by scoring them based on five parameters: related policies, added value (selling price), product resilience, competitiveness, and ease of processing. Besides having the potential for agricultural natural resources in the form of rice, sugar palm, and plants, another plantation in Landak District also has a large area of land that is designated for food crop agriculture.

Keywords: Industrial centers, agrotechnopark, IKM, palm sugar 


\section{Pendahuluan}

Dewasa ini Industri Kecil dan Menengah, maupun Industri Besar semakin meningkat jumlahnya dari tahun ke tahun. Sementara dengan terjadinya perubahan sistem dalam pemerintahan, setiap industri baik dari proses produksi, pemasaran, manajemen maupun pengendalian terhadap dampak lingkungan tidak dapat berlangsung secara kontinyu (Arsyad, 1999; Kristiyanti, 2012; Kuncoro, 2007). Hal ini sangat menghambat dalam perkembangan industri dan juga dalam memberikan peluang pasar atau kerjasama antar lintas sektor maupun antar Industri Kecil dan Menengah (IKM) dengan Industri Besar. Untuk itu perlu adanya program pengembangan Industri di Kabupaten Landak dalam rangka mendorong perkembangan ekonomi daerah dengan memanfaatkan potensi yang ada serta untuk menciptakan lapangan kerja. IKM termasuk salah satu kegiatan penggerak perekenomian masyarakat Kabupaten Landak, keberadaannya masih menyebar di berbagai kecamatan. Potensi dan peluang pengembangan IKM di Kabupaten Landak cukup baik sehingga pembinaannya perlu mendapat prioritas. Dengan ada dan tersebarnya IKM di Kabupaten Landak menyebabkan potensi IKM cukup bagus untuk dikembangkan, akan tetapi yang saat ini terjadi adalah perkembangan IKM masih belum dapat terdata secara utuh dalam penyajianya sehingga IKM Kabupaten Landak keberadaanya masih belum bersaing dengan wilayah lain.

Sentra IKM adalah lokasi pemusatan kegiatan industri kecil dan industri menengah yang menghasilkan produk sejenis, menggunakan bahan baku sejenis dan atau mengerjakan proses produksi yang sama, dilengkapi sarana dan prasarana penunjang (Gasperz, 2002; Kementerian Perindustrian Republik Indonesia, 2015). Kegiatan ini pada dasarnya upaya untuk mengembangkan industri kecil dan industri menengah yang berbasis sumber daya dan potensi daerah yang diwadahi secara terpadu dalam suatu Sentra IKM mandiri yang mampu menghasilkan nilai tambah serta menyerap tenaga kerja (Pawestri, 2015; Rochman, 2011; Wati, 2014; Wulandari, 2009).

Pengembangan Sentra IKM dinilai akan dapat membantu menunjang kegiatan industri pengolahan dalam skala kecil dan menengah. Perencanaan pengembangan sentra IKM Kabupaten Landak merupakan langkah awal dari pengembangan IKM Kabupaten Landak dengan menentukan kebutuhan sentra industri perkotaan Kabupaten Landak. Kebijakan penataan ruang Kabupaten Landak dalam bidang pertanian dan industri adalah sebagai berikut:

1. Pengembangan sentra produksi pertanian untuk mendukung pengembangan agribisnis.

2. Pengembangan kawasan agribisnis berbasis potensi wilayah pendukungnya.

3. Pengembangan kawasan industri yang handal dan berwawasan lingkungan.

4. Pengembangan infrastruktur wilayah untuk meningkatkan pengembangan jaringan dan aksesibilitas antara sentra produksi pertanian dengan kawasan agribisnis serta pasar.

Berdasarkan RTRW (Rencana Tata Ruang Wilayah) Kabupaten Landak, Kawasan peruntukan pertanian tanaman pangan meliputi lahan sekitar 60.000 ha tersebar di Sebangki Kompleks, Senakin Kompleks, Sompak Kompleks, dan seluruh kecamatan. Kawasan peruntukan pertanian hortikultura tersebar di seluruh kecamatan. Produk unggulan adalah produk yang potensial dikembangkan pada suatu wilayah dengan memanfaatkan SDA dan SDM lokal yang berorientasi pasar dan ramah lingkungan sehingga dapat memiliki keunggulan kompetitif dan siap menghadapi persaingan global (Ma'arif, 2002; Wibowo, dkk., 2011). Produk unggulan Sentra IKM di Kabupaten Landak ini akan ditentukan melalui skoring dengan parameter-parameter sebagai berikut (Ma'arif, 2002; Rochman, 2011).

1. Kebijakan terkait, yaitu kesesuaian program pada kebijakan Pemerintah Kabupaten Landak.

a. Skor 1 untuk tidak terprogramnya pada kebijakan.

b. Skor 2 untuk terprogramnya pada 1 kebijakan. 
c. Skor 3 untuk terprogramnya pada $>1$ kebijakan.

2. Nilai Tambah (Harga Jual) yaitu pertambahan nilai komoditas karena melalui proses pengolahan.

a. Skor 1 untuk produk yang tidak memiliki produk pasca pengolahan.

b. Skor 2 untuk produk yang memiliki 1 produk pasca pengolahan.

c. Skor 3 untuk produk yang memiliki $>1$ produk pasca pengolahan.

3. Ketahanan Produk, yaitu berkaitan dengan umur atau waktu daya tahan suatu produk.

a. Skor 1 untuk produk dengan daya tahan selama 1-3 bulan.

b. Skor 2 untuk produk dengan daya tahan selama 3-6 bulan.

c. Skor 3 untuk produk dengan daya tahan $>6$ bulan.

4. Daya Saing, yaitu kemampuan untuk berkompetisi dengan kompetitor atau pengusaha lainnya.

a. Skor 1 untuk produk yang memiliki daya saing rendah.

b. Skor 2 untuk produk yang memiliki daya saing sedang.

c. Skor 3 untuk produk yang memiliki daya saing tinggi.

5. Kemudahan dalam pengolahan, termasuk bahan dasar, tempat pengolahan serta tempat penyimpanan.

a. Skor 1 untuk produk dengan proses pengolahan yang sulit.

b. Skor 2 untuk produk dengan proses pengolahan sedang.

c. Skor 3 untuk produk dengan proses pengolahan mudah.

Stakeholder dalam pengembangan Sentra IKM memiliki kepentingan (interest) serta pengaruh (power) yang beragam, ada yang bersifat positif adapula yang bersifat negatif terhadap keberhasilan pengembangan sentra IKM. Kepentingan dan pengaruh dari setiap stakeholder dalam pengembangan sentra IKM yang beragam perlu dipetakan dengan jelas. Pemetaan stakeholder akan membantu pengelola bagaimana melibatkan stakeholder tersebut dalam pencapaian tujuan. Adapun skoring yang digunakan menggunakan skala 1-3 di atas, masing-masing memiliki kategori nilai sebagai berikut.

Tabel 1. Skoring Penentuan Produk Unggulan Kabupaten Landak

\begin{tabular}{|c|c|c|c|c|c|c|c|}
\hline No. & $\begin{array}{c}\text { Alternatif Produk } \\
\text { Unggulan }\end{array}$ & $\begin{array}{c}\text { Kebijakan } \\
\text { Terkait }\end{array}$ & $\begin{array}{c}\text { Nilai } \\
\text { Tambah }\end{array}$ & $\begin{array}{l}\text { Ketahanan } \\
\text { Produk }\end{array}$ & Daya Saing & $\begin{array}{c}\text { Kemudahan } \\
\text { dalam } \\
\text { Pengolahan }\end{array}$ & Total \\
\hline 1. & Penggilingan Padi & 3 & 2 & 2 & 1 & 3 & 11 \\
\hline 2. & Pengetaman Kayu & 1 & 2 & 3 & 1 & 3 & 10 \\
\hline 3. & Meubel & 1 & 3 & 3 & 2 & 2 & 11 \\
\hline 4. & Cetak Batako & 1 & 2 & 3 & 1 & 1 & 8 \\
\hline 5. & Bengkel Motor & 1 & 3 & 3 & 2 & 2 & 11 \\
\hline 6. & Bengkel Mobil & 1 & 3 & 3 & 2 & 1 & 10 \\
\hline 7. & Kerajinan Tangan & 1 & 3 & 3 & 3 & 2 & 12 \\
\hline 8. & Gula Aren & 2 & 3 & 3 & 3 & 3 & 14 \\
\hline 9. & Fotokopi/Percetakan & 1 & 3 & 3 & 1 & 3 & 11 \\
\hline 10. & Industri Logam & 1 & 3 & 3 & 2 & 1 & 10 \\
\hline 11. & $\begin{array}{l}\text { Bengkel } \\
\text { las/ketok/cat }\end{array}$ & 1 & 3 & 3 & 1 & 3 & 11 \\
\hline 12. & Industri makanan & 1 & 2 & 1 & 2 & 3 & 9 \\
\hline 13. & Gorden & 1 & 2 & 3 & 1 & 2 & 9 \\
\hline 14. & $\begin{array}{l}\text { Servis komponen } \\
\text { listrik }\end{array}$ & 1 & 2 & 3 & 1 & 3 & 10 \\
\hline 15. & Industri minuman & 1 & 2 & 1 & 2 & 3 & 9 \\
\hline
\end{tabular}


Hasil analisis dari skoring masing-masing parameter menunjukkan bahwa produk dengan skor tertinggi sebesar 14 poin yaitu gula aren menjadi prioritas produk unggulan. Berikut adalah alasan penguat mengapa gula aren perlu dikembangkan di Kabupaten Landak:

1. Pengembangan produk gula aren merupakan salah satu upaya untuk mengembangkan strategi pengembangan kawasan agribisnis berbasis potensi wilayah pendukungnya yang terprogram pada Rencana Tata Ruang Wilayah (RTRW) Kabupaten Landak Tahun 20142034.

2. Dari hasil analisis, dapat diketahui bahwa produk gula aren memiliki nilai tambah yang tinggi karena memiliki diversifikasi produk yang cukup tinggi pula. Prospek pengembangan aren dapat mendukung kebutuhan makanan seperti kolang kaling, tepung aren, nira aren, pati aren, nata pinnata, minuman ringan, cuka, alkohol, bahkan bahan bakar nabati yaitu bioethanol.

3. Tanaman aren memiliki daya adaptasi yang baik terhadap berbagai kondisi lahan dan agroklimat, serta toleransi tinggi dalam pola tanam campuran serta cepat tumbuh karena memiliki banyak akar dan tajuk lebat. Oleh karena itu, tanaman tersebut sangat cocok dikembangkan pada lahan-lahan marginal yang dimiliki oleh petani yang kurang mampu.

4. Adanya perhatian lebih dari pemerintah pusat untuk Program Industri Rumahan dengan sasaran produk gula aren dengan ditandatanganinya MoU dengan Kementerian Pemberdayaan Perempuan dan Perlindungan Anak RI dalam bidang Program Industri Rumahan.

5. Dengan adanya produk gula aren akan merangsang pertumbuhan sub-sektor yang dapat berpotensi membuka lapangan pekerjaan baru dan diharapkan dapat mengurangi angka pengangguran dan implikasinya yaitu mengurangi angka kemiskinan di Kabupaten Landak.

\section{Metodologi}

Metode yang digunakan dalam perencanaan pengembangan sentra industri (agrotechnopark gula aren) di kabupaten Landak disajikan pada penjelasan berikut ini.

\section{A. Membangun Brand Image}

Penetapan kawasan agroteknopark untuk industrialisasi aren. Strategi ini sangat penting dilakukan karena mengingat aren merupakan komoditas yang mempunyai nilai ekonomis tinggi dengan arti bahwa semua bagian aren dapat memberikan nilai tambah sehingga pembentukan kawasan agroteknopark yang mengolah produk hilir aren menjadi sangat penting untuk pengembangan dalam jangka panjang, dengan cara:

- Lebih memperkenalkan lagi bahwa Kecamatan Sebangki sebagai sentra industri gula aren.

- Mempertahankan ciri khas cita rasa produk dan meningkatkan kualitas produk agar tetap mampu bersaing dengan produk lain.

- Menciptakan inovasi dalam pengemasan produk, penambahan jenis produk agar memiliki daya tarik yang tinggi.

- Pengoptimalan pengelolaan usaha dengan menambah modal sehingga barang yang dihasilkan lebih maksimal.

- Bantuan dalam bentuk perkuatan modal untuk meningkatkan hasil produksi.

Agro Techno Park masuk ke dalam kategori TTP atau Taman Teknologi Pertanian yang di dalamnya meliputi beberapa kegiatan seperti pembelajaran bagaimana teknologi dalam pertanian. Kabupaten Landak merupakan wilayah yang memiliki potensi sumber daya alam yang memadai untuk suatu pembangunan Agro Techno Park. Selain memiliki potensi sumber 
daya alam pertanian berupa padi, aren, dan tanaman perkebunan lainnya, Kabupaten Landak juga memiliki lahan yang masih luas yang memang diperuntukkan untuk kawasan peruntukan pertanian tanaman pangan.

\section{B. Pengembangan Produk}

Pemberian bantuan berupa teknologi tepat guna untuk skala komersil dan teknologi packing. Strategi ini juga sangat penting karena untuk komersialisasi produk gula semut dan diversifikasi produk gula semut dan kemasan. Dengan adanya teknologi tepat guna untuk diversifikasi produk dan teknologi packaging dapat memperluas pasar gula semut aren (produk gula aren semut dapat di packing sesuai dengan permintaan). Parameter pengembangan suatu produk harus melihat model: Produksi, pengemasan, promosi, membangun kerjasama, dan pengembangan sumber daya manusia

\section{Rencana Hulu-Hilir Komoditi Gula Aren}

C.1. Rencana Input/Bahan Baku

Subsistem agribisnis hulu/agro input (up-stream agribusiness) merupakan keseluruhan kegiatan di sektor pertanian yang menghasilkan barang-barang modal untuk kebutuhan produksi pertanian seperti industri perbenihan/pembibitan, industri agro-kimia (pupuk dan pestisida), industri agro-otomotif (mesin dan peralatan produksi).

Komoditas unggulan yang dikembangkan di Kabupaten Landak yaitu sektor Perkebunan. Komoditas perkebunan yang akan dikembangkan adalah komoditas aren. Adapun upaya yang dapat dilakukan untuk mendukung subsistem agro input adalah:

1. Peningkatan pengetahuan proses produksi nira aren.

2. Peningkatan kualitas teknologi penanaman dan proses produksi.

3. Modernisasi peralatan produksi perkebunan.

\section{C.2. Rencana Proses}

Pengembangan agro proses (on farm) meliputi lahan, SDM, ruang produksi, keuangan, hingga olahan produk.

1. Peningkatan Sumber Daya Manusia

Peningkatan SDM menuju kemandirian petani dapat ditempuh dengan berbagai upaya:

a. Memulai dengan tindakan mikro dan lokal sehingga perlu pembelajaran agar berbagai pengalaman mikro dapat menjadi input bagi kebijakan pemerintah dan policy reform sehingga memiliki dampak yang lebih luas.

b. Pengembangan sektor ekonomi strategis berdasarkan kondisi lokal.

c. Membangun kembali kelembagaan masyarakat.

d. Mengembangkan penguasaan pengetahuan teknis dan kesadaran pelaku ekonomi.

e. Membangun jaringan ekonomi strategis.

2. Peningkatan Pembiayaan

a. Pengadaan lembaga keuangan yang mampu menyediakan modal usaha atau pinjaman.

b. Pemberian bantuan modal dari pemerintah melalui program kredit tanpa bunga.

3. Peningkatan Teknologi Produksi

a. Pemilihan dan pengembangan jenis tanaman aren yang memiliki kualitas unggul sesuai dengan tujuan pemanfaatannya.

b. Melakukan proses perawatan secara benar.

c. Melakukan perawatan dan pemeliharaan tanaman aren secara teratur dengan cara melaksanakan pengecekan secara berkala. 
d. Pengadaan sarana pengolahan seperti: pabrik pengolahan gula aren sesuai standar yang layak.

e. Pengadaan sarana penunjang seperti: pembangkit listrik/generator listrik, telepon, sarana air bersih untuk pembersihan dan pengolahan gula aren.

\section{C.3. Rencana Output}

Pengembangan sub sistem agro output dan pemasaran mencakup pengembangan produk hasil perkebunan dan hasil pengolahan, limbah, serta sistem pemasaran yang mencakup sarana prasarana pemasaranan serta informasi pasar.

1. Perluasan Jaringan Pemasaran.

2. Peningkatan Sarana Prasarana Pengelolahan.

3. Peningkatan Pasca Panen.

4. Pembentukan kemitraan antara petani dengan perusahaan yang menjadikan sebagai bahan baku.

\section{C.4. Rencana Pengembangan Produk Gula Aren}

Berdasarkan hasil produksi tanaman aren di Kabupaten Landak, maka komoditas ini dinyatakan sebagai komoditas yang dapat diunggulkan bagi peningkatan perekonomian masyarakat setempat. Lokasi sebaran hinterland sebagai daerah penghasil komoditas aren adalah di Desa Kumpang Tengah.

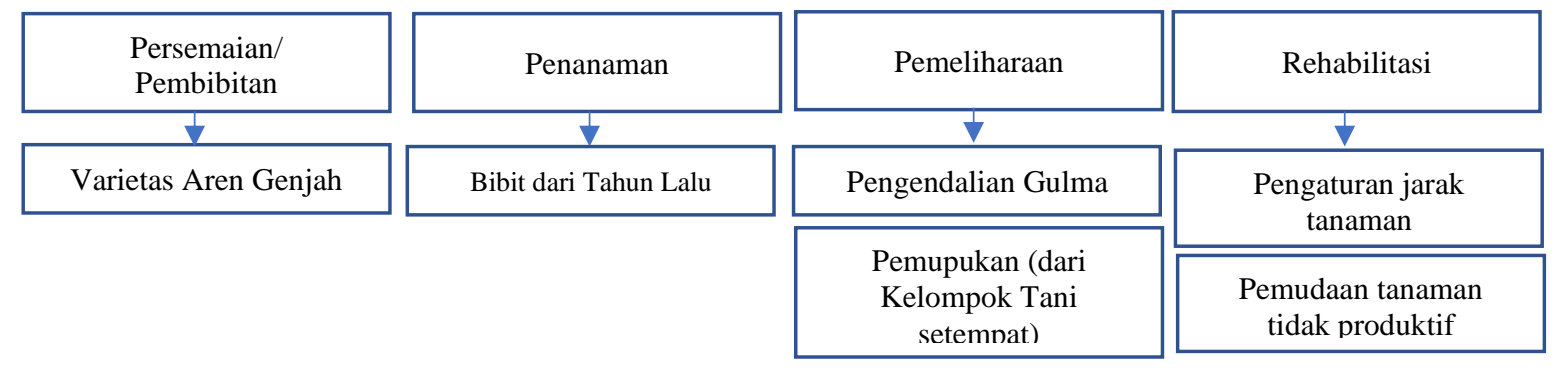

Gambar 1. Sub Sistem Agro Input Komoditas Gula Aren

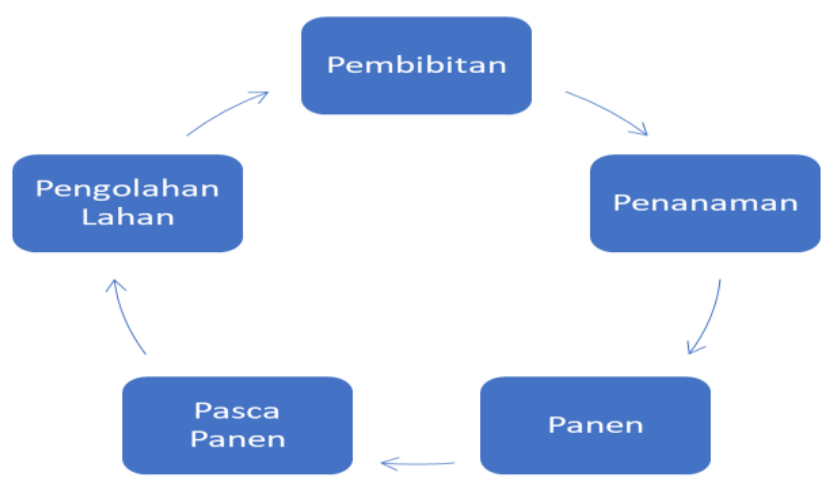

Gambar 2. Sub Sistem Agro Usaha Tani (On Farm) Komoditas Aren

Budidaya tanaman aren membutuhkan waktu yang cukup lama dengan proses pertama yaitu persemaian atau pembibitan yang menggunakan varietas Aren Genjah karena varietas tersebut cukup potensial. Selain karena pohonnya pendek dan cepat menghasilkan, produksi nira tinggi sekitar 12 liter per hari dan periode penyadapan per mayang cukup lama yaitu $>2$ bulan. Kemudian setelah penanaman, pemeliharaan yaitu terdiri atas pengendalian gulma dan 
pemupukan. Dalam sub sistem agro usaha tani (on farm) komoditas aren, poses pertama adalah persemaian atau pembibitan, kemudian penanaman tanaman aren dan dilanjutkan dengan panen. Panen pada tanaman aren yaitu dilakukan penyadapan nira aren dari bunga aren yang baru terbentuk pada umur sekitar 12-16 tahun. Setelah panen, nira aren tersebut diolah menjadi produk-produk gula aren.

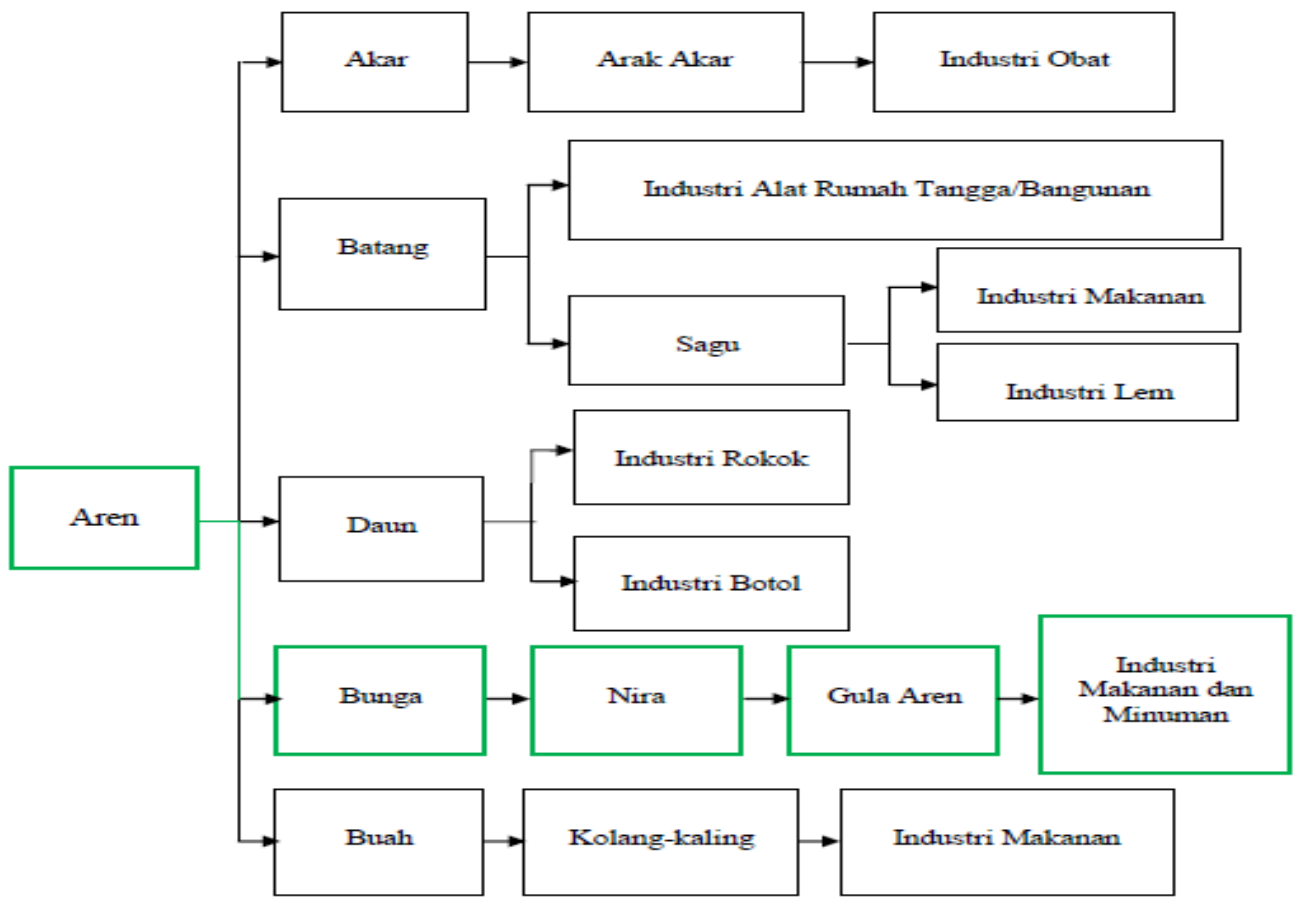

Gambar 3. Sub Sistem Agro Output dan Pemasaran Komoditas Aren

Dari Gambar 3 dapat diketahui bahwa seluruh bagian tanaman aren dapat dimanfaatkan dan diolah menjadi banyak produk dari berbagai macam industri. Namun untuk perencanaan pengembangan sentra IKM di Kabupaten Landak, penggunaan aren sebagai gula aren untuk industri makanan dan minuman adalah yang akan dikembangkan lebih lanjut sampai ke pemasaran hasil komoditas.

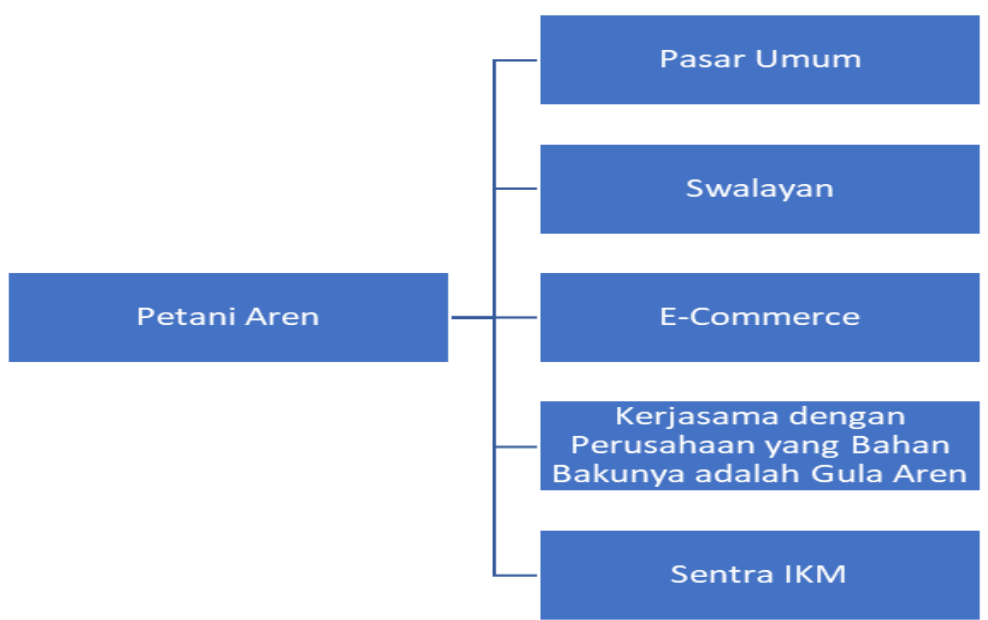

Gambar 4. Sistem Pemasaran Hasil Komoditas Aren 


\section{C.5. Rencana Tapak Kawasan}

Rencana tapak kawasan yang direncanakan sebagai sentra Industri Kecil Menengah (IKM) di Kabupaten Landak berada di Kecamatan Sebangki tepatnya di Desa Kumpang Tengah, Dusun Ampar Pancur. Saat ini status kepemilikan lahan milik Kepala Desa Kumpang Tengah. Lokasi rencana sentra IKM Sebangki tersebut berdekatan dengan perumahan Komunitas Adat Terpencil. Adapun luasan dari tapak yang sudah dipersiapkan untuk sentra IKM sekitar 8 ha.

Berdasarkan luas total lahan yang telah tersedia untuk SIKM Sebangki, dilakukan pembagian untuk lahan terbangun dan lahan tak terbangun. Lahan terbangun digunakan untuk kantor, showroom, sarana dan prasarana, sedangkan lahan tak terbangun digunakan untuk lahan budidaya tanaman nira dan beberapa tanaman lain yang akan diolah dan diproduksi menjadi barang jadi yang siap untuk dipasarkan.

\section{C.5.1. Zona Pengumpulan Bahan Baku}

Daerah pengumpul bahan baku merupakan desa-desa yang lokasinya terletak berdekatan di sekitar pusat agropolitan atau pusat-pusat pertumbuhan yang direncanakan dalam konsep agropolitan. Fungsi yang diperankan oleh desa-desa ini adalah sebagai pengumpul dan pengolah bahan baku untuk disuplai ke kota pusat pertumbuhan agropolitan sebagai uplandnya. Dalam analisis ini, beberapa desa yang dapat diskenariokan sebagai desa pengumpul bahan baku antara lain Desa Kumpang Tengah. Fungsi yang dapat dijalankan oleh beberapa pusat ini antara lain sebagai berikut;

1. Sebagai kota perdagangan yang berorientasi ekspor keluar daerah.

2. Pusat kegiatan manufacturing final industri pertanian (packing).

3. Pusat kegiatan tersier agrobisnis dan jasa perdagangan skala besar.

Adapun alternatif fungsi yang dapat disematkan kepada pusat-pusat desa pengumpul ini antara lain:

1. Pusat perdagangan wilayah yang ditandai dengan adanya pasar-pasar grosir dan pergudangan komoditas sejenis.

2. Pusat kegiatan agro-industri berupa pengolahan barang pertanian jadi dan setengah jadi serta kegiatan agro-bisnis.

3. Pusat pelayanan agro-industri khusus (special agro-industry services), pendidikan, pelatihan dan pemuliaan tanaman unggulan.

\section{C.5.2. Zona Produksi}

Zona Produksi merupakan zona inti atau titik dimana industri kecil dan menengah akan berkumpul untuk melaksanakan proses produksi. Zona produksi gula aren di Kabupaten Landak berdasarkan hasil analisis akan berada di Desa Sebangki, Desa Agak dan Desa Kumpang Tengah karena kondisi eksisting produksi berada di 3 (tiga) desa tersebut. Selain itu, Desa Sebangki, Desa Agak dan Desa Kumpang Tengah memiliki jarak yang lebih dekat dengan perkebunan aren sebagai pusat supply produk gula aren.

\section{C.5.3. Zona Packaging}

Zona Packaging atau packing house diharapkan dapat membantu memperpanjang masa simpan produk dan meningkatkan daya tarik produk. Pemilihan zona packaging harus memenuhi beberapa persyaratan sebagai berikut:

1. Memiliki akses jalan, air bersih, sanitasi dan listrik serta akses ke sumber pasokan.

2. Mendapat izin lingkungan.

3. Bebas pencemaran dan higienis.

Oleh karena itu, zona packaging yang memenuhi syarat adalah Desa Sei Sagak. 


\section{C.5.4. Zona Showroom}

Showroom produk komoditas gula aren digunakan untuk memajang produk-produk hasil olahan dari komoditas gula aren Kabupaten Landak. Showroom merupakan kunci dalam promosi dan pendistribusian produk gula aren yang dapat menjadi karakter kawasan industri khususnya pada produk unggulan gula aren di Kabupaten Landak. Showroom pada sentra IKM di Kabupaten Landak nantinya akan terletak di Desa Rantau Panjang karena desa tersebut adalah desa yang paling dekat dengan Kota Pontianak dan berada pada pintu masuk Kecamatan Sebangki.

\section{C.5.5. Zona IPTEK}

Zona IPTEK adalah zona pusat penelitian dan pengembangan produk aren dan gula aren. Pusat penelitian ini nantinya akan dikelola oleh tenaga profesional di bidang pertanian dan perkebunan. Zona IPTEK akan berada pada Desa Rantau Panjang berdekatan dengan Zona Showroom.

\section{Rencana Sarana dan Prasarana Penunjang}

\section{D.1. Sarana}

Sejumlah sarana pendukung pengembangan Sentra IKM di Kabupaten Landak meliputi pusat pengembangan iptek, gudang pengumpul hasil, packing house, showroom produk komoditas, ruang workshop, bangunan produksi. Sentra IKM tersebut nantinya dapat berfungsi sebagai tujuan eduwisata mengenai kawasan agrobisnis dan sentra IKM mulai dari pengolahan hulu hingga ke hilir. Sentra IKM akan dilengkapi oleh berbagai sarana penunjang untuk lebih meningkatkan pengelolaan komoditas pada daerah penghasilnya.

1. Pusat pengembangan IPTEK yang akan dikelola oleh tenaga profesional di bidang pertanian dan perkebunan. Pada sarana ini akan dikembangkan berbagai macam inovasi produk gula aren.

2. Gudang pengumpul hasil panen dari kawasan perkebunan di sekitarnya untuk diolah lebih lanjut.

3. Packing house khusus untuk pengemasan produk gula aren.

4. Showroom produk komoditas digunakan untuk memajang produk hasil olahan dari komoditas gula aren.

5. Ruang workshop untuk memberikan penyuluhan kepada masyarakat berkaitan dengan konsep agro agar seluruh masyarakat dapat terlibat aktif. Selain itu, ruang workshop ini juga berfungsi sebagai tempat sosialisasi atau edukasi bagi pengunjung yang ingin mengetahui tentang Sentra IKM Kabupaten Landak.

\section{D.2. Prasarana}

Prasarana pendukung yang dapat menunjang pengembangan sentra IKM di Kabupaten Landak adalah jaringan jalan, air bersih, IPAL dan Tempat Pembuangan Sampah (TPS).

1. Jaringan Jalan

Sesuai dengan kriteria dan kondisi yang ada di wilayah Kabupaten Landak, secara umum jaringan jalan yang ada Kabupaten Landak sudah cukup memadai khususnya jaringan jalan yang menghubungkan antar kecamatan maupun pusat-pusat pelayanan. Arahan rencana pengembangan jaringan jalan untuk mendukung pengembangan Sentra IKM di Kabupaten Landak adalah sebagai berikut:

a. Perbaikan dan peningkatan kualitas jalan dengan prioritas utama pada jaringan jalan utama yang menghubungkan antar wilayah kecamatan, peningkatan kualitas jalan 
yang menghubungkan dengan wilayah sekitar Kabupaten Landak, peningkatan kualitas jalan yang menghubungkan ke kawasan potensial dan lain sebagainya, khususnya yang saat ini kondisi jalannya mengalami kerusakan atau mengarah pada kondisi rusak.

b. Pengembangan jaringan jalan yang menghubungkan ke kawasan-kawasan potensial dan strategis.

2. Jaringan Air Bersih

Pengembangan jaringan air bersih untuk prasarana penunjang pengembangan Sentra IKM di Kabupaten Landak dilakukan melalui:

a. Penggunaan sistem instalasi penyediaan air jaringan perpipaan dengan memanfaatkan sungai dan danau.

b. Pemanfaatan air tanah.

3. Jaringan Kelistrikan

Jaringan kelistrikan di Kecamatan Sebangki Kabupaten Landak sangat penting untuk proses produksi pengolahan gula aren. Namun, masih terdapat desa yang belum dialiri oleh listrik yaitu Desa Kumpang Tengah sedangkan Desa Kumpang Tengah sendiri merupakan desa yang memproduksi tanaman aren untuk bahan baku gula aren. Sehingga perlu adanya pengaliran listrik di Desa Kumpang Tengah untuk menunjang pengembangan Sentra IKM di Kabupaten Landak.

4. IPAL (Instalasi Pengolahan Air Limbah)

Adanya Sentra IKM dengan konsep Agroteknopark tentu akan menghasilkan limbah. Limbah dari hulu hingga ke hilir ini memiliki andil dalam menciptakan pencemaran lingkungan. Oleh karena itu, untuk meminimalisir pencemaran lingkungan, perlu adanya IPAL untuk mengelola limbah lebih lanjut sehingga tidak mencemari lingkungan dan tidak membahayakan. Gambar 5 menunjukkan sistem pengelolaan limbah di sentra IKM. Limbah dari industri sebelum masuk ke IPAL terpadu harus dilakukan kontrol kualitas terlebih dahulu. Hal ini dilakukan untuk menjaga agar karakteristik limbah yang masuk tidak mempunyai fluktuasi yang terlalu besar agar tidak mengganggu proses pengolahan. Dengan adanya sistem kontrol limbah ini maka bagi industri yang menghasilkan limbah dengan karakteristik di atas standar yang diberlakukan harus melakukan pre-treatment terhadap limbahnya terlebih dahulu sampai diperoleh standar kualitas limbah yang boleh masuk ke IPAL. Sedangkan bagi industri yang menghasilkan limbah dengan karakteristik yang sama dengan kualitas limbah yang diperboleh dapat langsung disalurkan ke dalam IPAL. Di outlet limbah setiap industri juga perlu dipasang alat ukur debit limbah, sehingga jumlah limbah yang disalurkan ke IPAL dapat dipantau. Jumlah limbah yang disalurkan ini akan menentukan jumlah biaya yang harus ditanggung oleh industri bersangkutan. Air limpasan saluran harus dipisahkan dari saluran limbah agar IPAL tidak menerima beban limbah yang terlampau besar.

5. Tempat Penampungan Sementara (TPS)

Adapun rencana dalam pengelolaan sistem persampahan, yaitu:

a. Pelaksanaan restrukturisasi instansi teknis pengelola sampah.

b. Pembangunan calon TPA sebagai lokasi pengolahan sampah dengan teknologi tinggi yang dilengkapi dengan sistem sanitary landfill.

c. Pelaksanaan pemilahan sampah.

d. Pelaksanaan kerjasama dengan pihak swasta lainnya dengan penekanan kepada teknologi yang mengolah sampah organik dan pembangunan unit-unit daur ulang. 
e. Pelaksanaan kampanye massal mengenai 3R (reuse, recycle dan reduce) kepada masyarakat.

f. Pelaksanaan evaluasi terhadap kelembagaan instansi teknis pengelola sampah.

g. Pelaksanaan evaluasi total terhadap sistem pengelolaan retribusi sampah dalam rangka meningkatkan perolehan retribusi; Pengolahan sampah dengan prinsip 3R (Reuse, Reduce, Recycle) dan composting.

h. Peningkatan manajemen sistem pengangkutan sampah.

i. Melakukan pemisahan jenis sampah.

j. Penyediaan sarana persampahan terutama di pusat kegiatan.

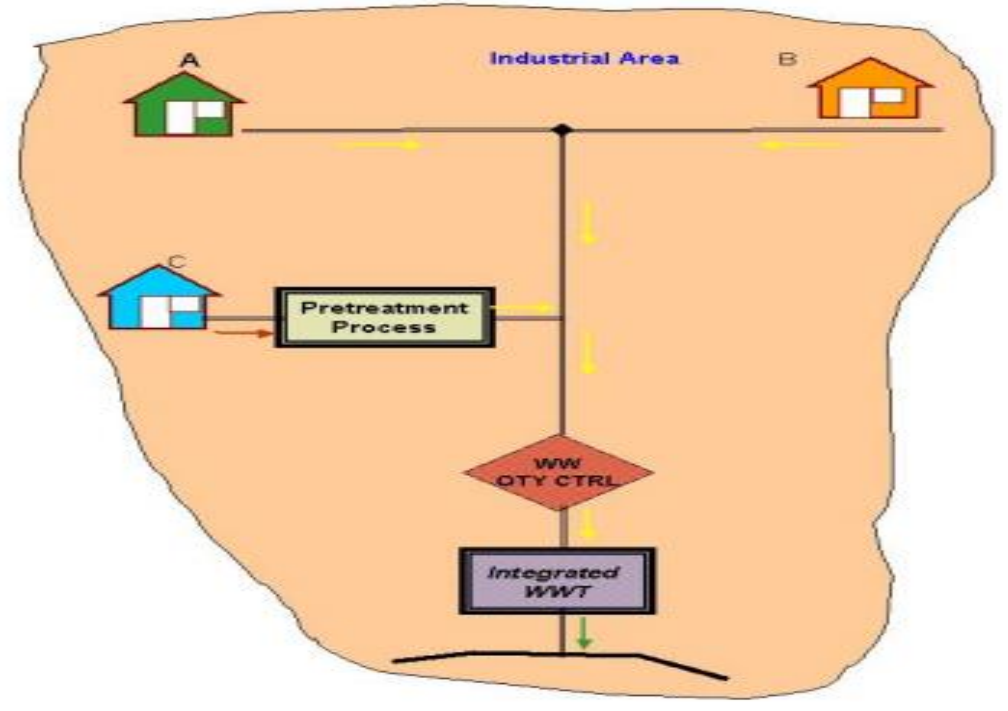

Gambar 5. Sistem Pengelolaan Limbah Sentra Industri Kecil

\section{E. Pembuatan Regulasi}

Kebijakan dan sanksi bagi yang menjual dalam bentuk tuak. Strategi ini sangat penting untuk diterapkan karena untuk memutus rantai pemasaran tuak yang sebenarnya merugikan pengusaha aren. Kebijakan perlu dibuat untuk memberikan rasa takut dan merupakan bentuk ketegasan akan larangan penjualan dalam bentuk tuak.

\section{F. Indikasi Program}

Pengembangan Sentra IKM di Kabupaten Landak akan direncanakan dalam 3 tahapan. Tiap tahapan akan berlangsung dalam waktu yang berbeda-beda tergantung kerumitan pekerjaannya. Oleh karena itu, menurut analisis perhitungan waktu keseluruhan yang dibutuhkan dalam Pembangunan Sentra IKM Kabupaten Landak akan tuntas dalam waktu 10 tahun. Adapun tahapan dalam pembangunan kawasan agroindustri di Kabupaten Landak yaitu sebagai berikut:

1. Tahap Perencanaan yaitu meliputi Studi Kelayakan (Feasibility Study), Penyusunan Rencana Induk (Master Plan), Studi Kelayakan Lingkungan (AMDAL/UKL/UPL), Penyusunan DED Kawasan Sentra IKM dan Studi Analisis Mengenai Dampak Lalu Lintas (ANDALALIN).

2. Pra Kontruksi meliputi Pembebasan Lahan, Pematangan Lahan, Pembuatan Perda Terkait dan Pengurusan Ijin.

3. Tahap Pembangunan/ Kontruksi meliputi Pembangunan Jalan Utama, Jalan Primer, Jalan Sekunder, Jaringan Drainase, Area Pergudangan, Penerangan Jalan Umum, Pembangunan 
RTH, IPAL, Pusat Perdagangan, Pembangunan TPS, Jaringan Air Bersih, Sanitasi, Substansi Kerusakan Jalan, Perumahan Untuk Pekerja, gedung kantor pengelola, fasilitas kesehatan, unit pemadam kebakaran, area parkir, Jembatan timbang dan gedung, Fasilitas umum dan pendukung lainnya, Promosi, Biaya pemeliharaan sarana dan prasarana, Biaya asuransi, Biaya Kerusakan Lingkungan akibat alih fungsi lahan dan Biaya Kesehatan yang timbul akibat polusi dari pembangunan.

\section{Hasil dan Pembahasan}

\section{A. Analisis Penentuan Lokasi Pengembangan Sentra Industri IKM Gula Aren}

Berdasarkan RTRW Kabupaten Landak Tahun 2014-2034, kawasan peruntukan pertanian tanaman pangan meliputi lahan sekitar 71.400 ha tersebar di Sebangki Kompleks, Senakin Kompleks, Sompak Kompleks, dan seluruh kecamatan. Selain itu, arahan RTRW terdapat Kawasan Strategis Kabupaten (KSK) berupa Kawasan KUAT (Kawasan Usaha Agribisnis Terpadu) yaitu Kecamatan Sebangki, Kecamatan Senakin dan Kecamatan Sompak.

Selanjutnya, dari ketiga kecamatan yaitu Kecamatan Sebangki, Kecamatan Senakin dan Kecamatan Sompak, kemudian dilanjutkan tinjauan terhadap beberapa kriteria penentuan lokasi pengembangan Sentra Industri IKM Gula Aren berdasarkan Peraturan Menteri Perindustrian RI No. 40/M-IND/PER/6/2016. Adapun ketentuan teknisnya disajikan pada Tabel 2.

Tabel 2. Kriteria Penentuan Lokasi Industri

\begin{tabular}{ll}
\hline \multicolumn{1}{c}{ Alternatif } & \multicolumn{1}{c}{ Jarak kepusat kota } \\
\hline Jarak kepusat kota & Minimal $10 \mathrm{~km}$ \\
Jarak terhadap permukiman & Minimal $2 \mathrm{~km}$ \\
Jaringan transportasi darat & Tersedia jalan arteri primer atau jaringan kereta api \\
Jaringan energi dan kelistrikan & Tersedia \\
Prasarana Angkutan & Tersedia pelabuhan laut untuk kelancaran transportasi logistik \\
Sumber Air Baku & barang maupun outlet ekspor/impor \\
Topografi & Tersedia sumber air permukaan (sungai, danau, waduk/ \\
Kesuburan tanah & Maksimg, laut) dengan debit \\
Pola tata guna lahan & Relatif tidak subur (non irigasi teknis) \\
Ketersediaan lahan & Non-pertanian, non permukiman dan non konservasi \\
Harga lahan relatif & Minimal 50 ha \\
\hline Sumber: Kementerian Perindustrian, & Bukan merupakan lahan dengan harga yang tinggi di daerah \\
\end{tabular}


Berdasarkan kategori penentuan lokasi industri dapat ditentukan lokasi Sentra Industri IKM Gula Aren yakni terletak pada Kecamatan Sebangki. Adapun pemenuhan kriteria lokasi pengembangan Sentra Industri IKM Gula Aren pada kawasan tersebut antara lain:

1. Jarak ke pusat kota yaitu $63 \mathrm{~km}$ (standar minimal $10 \mathrm{~km}$ ).

2. Tersedia jaringan listrik, energi dan telekomunikasi.

3. Ketersediaan lahan lebih dari standar (50 Ha) yang disebutkan pada RTRW Kabupaten Landak Tahun 2014-2034 dimana tanah seluas 71.400 Ha tersebar di Sebangki Kompleks, Senakin Kompleks dan Sompak Kompleks yang ditunjuk sebagai peruntukan pertanian tanaman pangan meliputi Kawasan perlindungan lahan pertanian pangan berkelanjutan dan kawasan perlindungan lahan cadangan pertanian pangan berkelanjutan.

\section{B. Analisis Diversifikasi Produk dan Nilai Tambah}

Hasil olahan gula aren misalnya pembuatan sirup gula aren, grubi, gula kacang, ting-ting, permen caramel, dan bolu kukus. Sirup Gula Aren merupakan salah satu variasi dari olahan gula aren. Sirup Gula Aren ini dibuat melalui proses tidak terlalu sulit dan lama namun mempunyai citarasa yang tak perlu diragukan lagi. Sirup Gula Aren memiliki variasi rasa jahe dan stroberry.

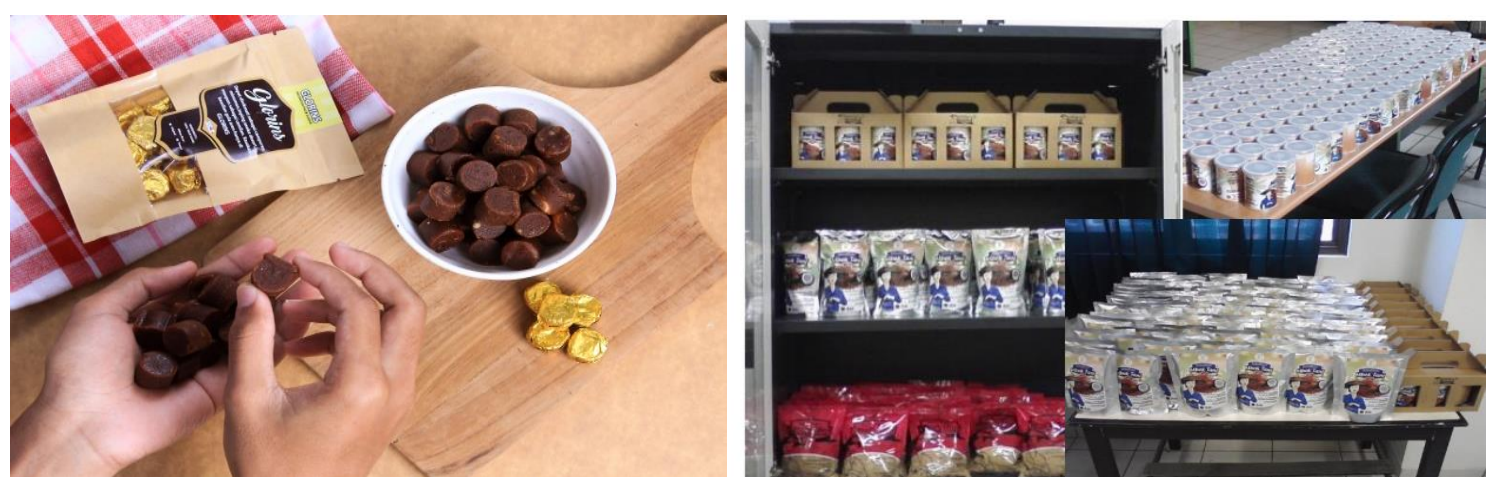

Gambar 8. Gula Semut dalam Kemasan

\section{Analisis Nilai Tambah}

Analisis nilai tambah ini akan memberikan informasi mengenai faktor-faktor dari proses produksi yang menghasilkan atau meningkatkan nilai tambah atau sebaliknya. Perhitungan nilai tambah bertujuan untuk mengetahui besarnya nilai tambah dalam satu liter nira setelah diolah menjadi gula semut aren. Besaran nilai tambah tergantung pada biaya yang dikeluarkan meliputi biaya perolehan bahan baku dan input lainnya. Input lain tersebut terdiri dari seluruh biaya variabel kecuali biaya bahan baku dan upah tenaga kerja. Harga jual yang akan dijadikan patokan untuk perhitungan nilai tambah produk bersumber dari beberapa $E$-Commerce.

\section{Analisis Manfaat}

Gula aren merupakan salah satu yang masuk program pemerintah dalam diversifikasi industri gula nasional. Pembangunan industri gula aren sebagai salah satu alternatif sumber gula alami non tebu. Gula aren ini memiliki kelebihan, yakni nilai nutrisi yang tinggi dibandingkan gula tebu serta memiliki aroma dan rasa yang khas. Selain itu, dalam proses pengolahannya tidak memakai bahan kimia sehingga banyak diminati oleh pasar ekspor.

Produksi gula aren menjadi berbagai macam produk ini setelah dibuat, pembuat gula aren memasarkan produk tersebut kepada pihak-pihak tertentu yang sering memesan. Namun, jika 
tidak ada pesanan, maka produk gula aren ini dijual kepada pedagang lokal atau industri kecil dan menengah yang setiap hari mengambil produknya.

Tabel 4. Potensi dan Hambatan

\section{Potensi}

- Luas lahan yang tersedia masih banyak

- Omset

- Kapasitas produksi gula aren

Tantangan dan Hambatan

- Industri Gula Aren di Kabupaten Landak masih tergolong tradisional, sehingga sebagian besar belum memiliki legalitas usaha

- Modal kerja yang terbatas dan kurangnya akses ke sumber pendanaan

- Pemasaran masih sangat tergantung pada tengkulak, sehingga pengusaha gula aren sulit untuk mendapatkan harga jual yang tinggi

- Rendahnya kualitas SDM

- Belum adanya teknologi yang mumpuni dalam produksi gula aren, karena masih menggunakan kayu bakar. Hal ini tentunya berpotensi juga untuk merusak lingkungan

\section{E. Analisa Tapak Kawasan}

Rencana tapak kawasan yang direncanakan sebagai sentra Industri Kecil Menengah (IKM) di Kabupaten Landak berada di Kecamatan Sebangki tepatnya di Desa Kumpang Tengah, Dusun Ampar Pancur. Saat ini status kepemilikan lahan milik Kepala Desa Kumpang Tengah. Lokasi rencana sentra IKM Sebangki tersebut berdekatan dengan perumahan Komunitas Adat Terpencil. Adapun luasan dari tapak yang sudah dipersiapkan untuk sentra IKM sekitar 8 ha.

Berdasarkan luas total lahan yang telah tersedia untuk SIKM Sebangki, dilakukan pembagian untuk lahan terbangun dan lahan tak terbangun. Lahan terbangun digunakan untuk kantor, showroom, sarana dan prasarana, sedangkan lahan tak terbangun digunakan untuk lahan budidaya tanaman nira dan beberapa tanaman lain yang akan diolah dan diproduksi menjadi barang jadi yang siap untuk dipasarkan. Perbandingan lahan terbangun dan tak terbangun sebesar 50:50. Gambar 9 dan 10 merupakan ilustrasi siteplan sentra IKM Sebangki.

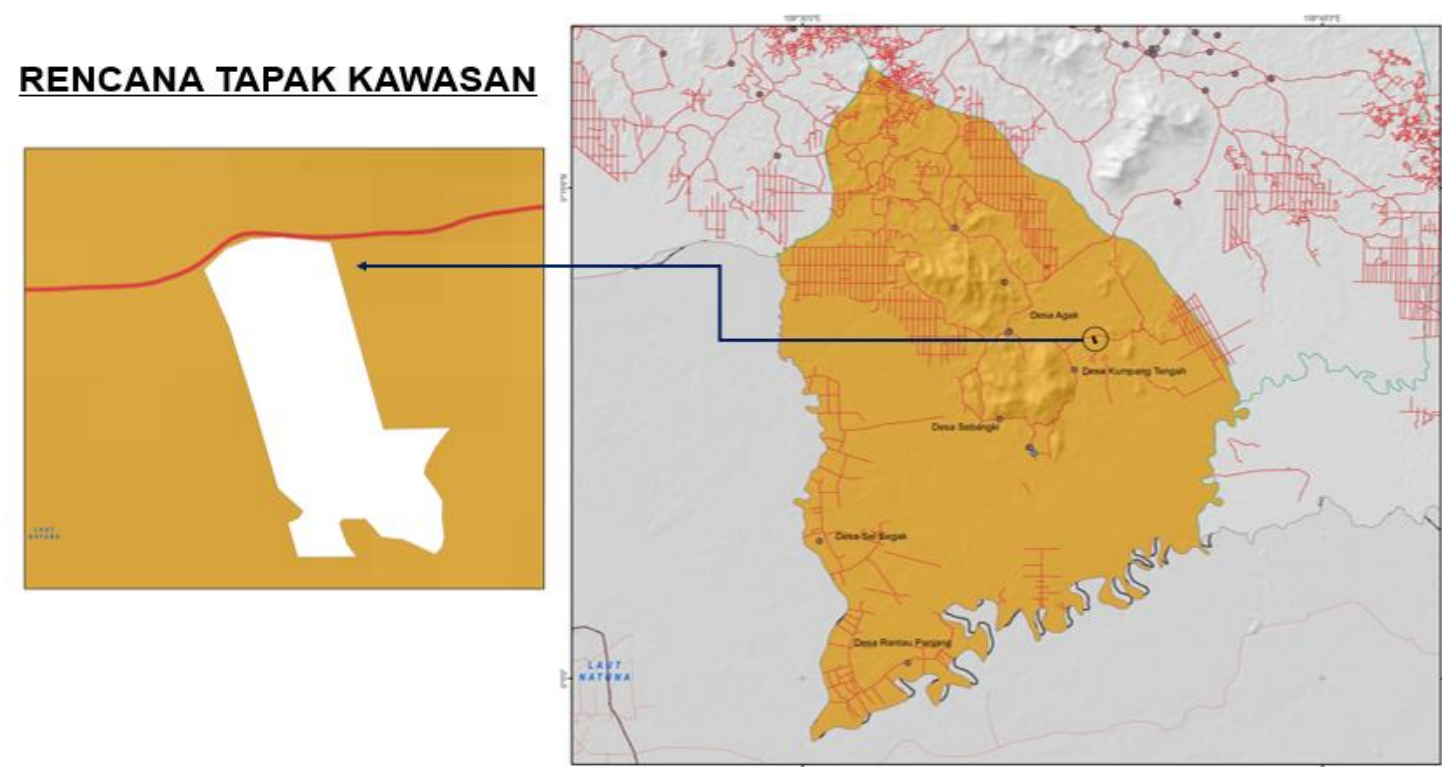

Gambar 9. Titik Lokasi Rencana Sentra IKM Sebangki 


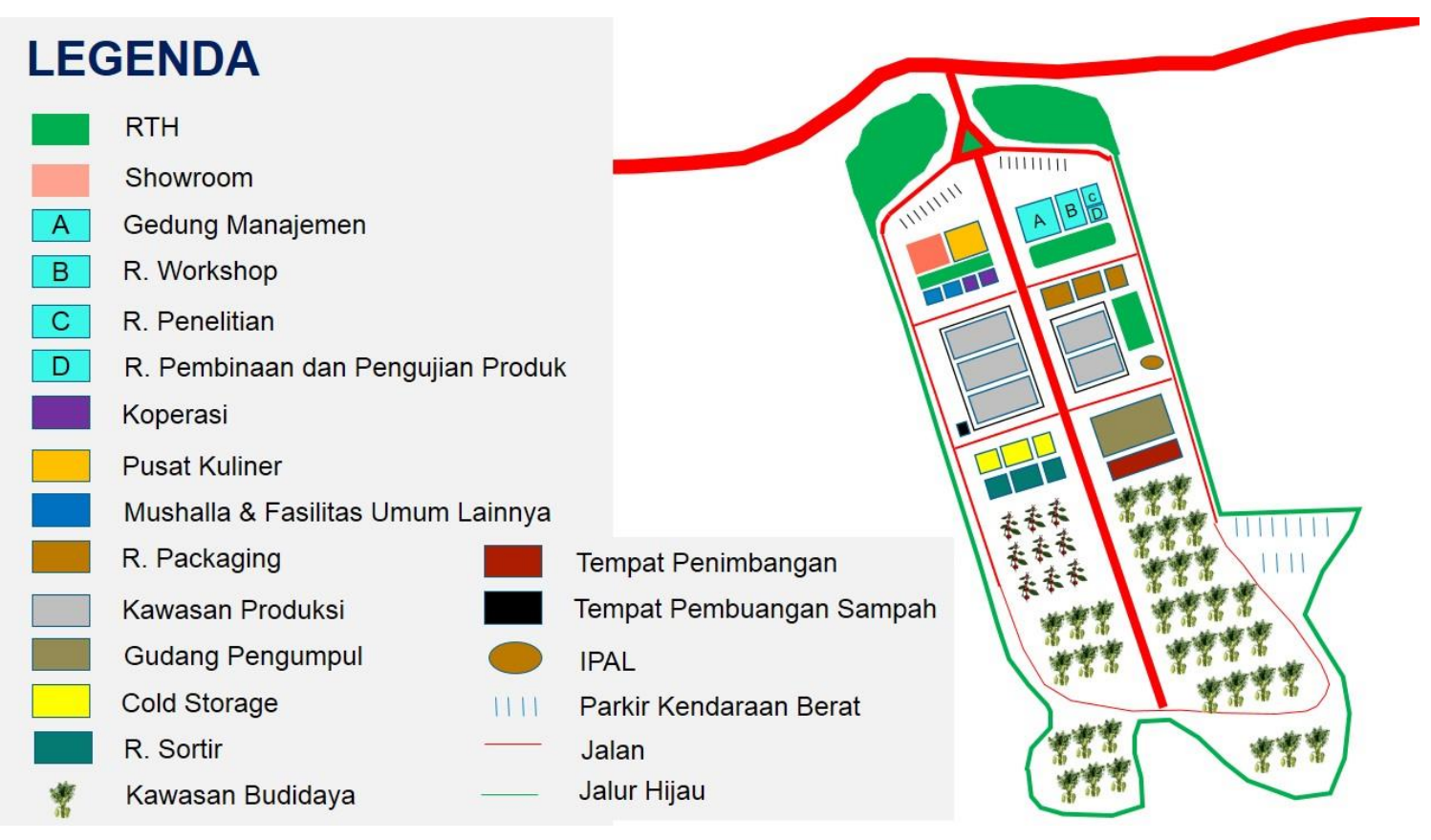

Gambar 10. Siteplan Sentra IKM Sebangki, Kabupaten Landak

\section{F. Simpulan}

Penetapan kawasan agroteknopark untuk industrialisasi aren merupakan strategi yang sangat penting dilakukan mengingat aren merupakan komoditas yang mempunyai nilai ekonomis tinggi. Semua bagian aren dapat memberikan nilai tambah sehingga pembentukan kawasan agroteknopark yang mengolah produk hilir aren menjadi sangat penting untuk pengembangan dalam jangka Panjang, yaitu:

- Lebih memperkenalkan lagi bahwa Kecamatan Sebangki sebagai sentra industri gula aren.

- Mempertahankan ciri khas cita rasa produk dan meningkatkan kualitas produk agar tetap mampu bersaing dengan produk lain.

- Menciptakan inovasi dalam pengemasan produk, penambahan jenis produk agar memiliki daya tarik yang tinggi.

- Pengoptimalan pengelolaan usaha dengan menambah modal sehingga barang yang dihasilkan lebih maksimal.

- Bantuan dalam bentuk perkuatan modal untuk meningkatkan hasil produksi.

Agrotechnopark masuk ke dalam kategori Taman Teknologi Pertanian (TTP) yang di dalamnya meliputi beberapa kegiatan seperti pembelajaran bagaimana teknologi dalam pertanian. Kabupaten Landak merupakan wilayah yang memiliki potensi sumber daya alam yang memadai untuk suatu pembangunan kawasan agrotechnopark. Selain memiliki potensi sumber daya alam pertanian berupa padi, aren, dan tanaman perkebunan lainnya, Kabupaten Landak juga memiliki lahan yang masih luas yang memang diperuntukkan untuk kawasan peruntukan pertanian tanaman pangan. Peningkatan komitmen dan kerja sama antara semua stakeholder aren dalam penguatan agroindustri aren (kemitraan dengan perusahaan pengguna). Strategi ini sangat penting mengingat belum adalnya komitmen dari semua stakeholder baik itu pemerintah, petani aren, dan swasta. Komitmen dan kerja sama yang sangat diharapkan dalam bentuk kemitraan dengan perusahaan pengguna produk gula semut untuk kepastian pemasaran. 


\section{Ucapan Terima Kasih}

Penulis mengucapkan terima kasih kepada DPRD dan Bupati Kabupaten Landak, BAPPEDA, Dinas Pertanian, Dinas Perikanan dan Ketahanan Pangan, Dinas Koperasi, Usaha Kecil dan Menengah Perindustrian dan Perdagangan, Dinas Penanaman Modal, Pelayanan Terpadu Satu Pintu dan Tenaga Kerja, Dinas Pekerjaan Umum dan Penataan Ruang, Badan Pertanahan, Dinas Perumahan Rakyat, Kawasan Permukiman dan Lingkungan Hidup Kabupaten Landak yang telah membantu pelaksanaan kegiatan pengabdian masyarakat ini.

\section{Daftar Pustaka}

Arsyad, L. 1999, Pengantar perencanaan dan pengembangan Ekonomi Daerah, Edisi Pertama, BPFE Jakarta Baskoro, Haryadi (2005). All About Healing. Yogyakarta: Andi.

Evalia, N. A. 2015, Strategi pengembangan agroindustri gula semut aren.Jurnal Manajemen \& Agribisnis, 12(1), 57-56.

Gasperz, V. 2002, Manajemen Kualitas Dalam Industri Jasa. Jakarta: Gramedia Pustaka Utama.

Kementerian Perindustrian Republik Indonesia, Pembangunan Sumber Daya Industri 2015, http://bdijakarta.kemenperin.go.id. Diakses tanggal 10 maret 2018 pk 23.00 WIB.

Kristiyanti, Mariana. 2012, Peran Strategis Usaha Kecil Menengah (UKM) Dalam Pembangunan Nasional. Majalah Ilmiah INFORMATIKA Vol. 3 No. 1, hal. 63-89.

Kuncoro, M. 2007, Ekonomi Industri Indonesia. Yogyakarta: Andi Offset.

Ma'rif, S. 2002, Ekonomi Wilayah dan Kota, Ekonomika dalam Perencanaan Identifikasi Sektor Strategis. Semarang: UNDIP.

Pawestri, F. C. 2015, Upaya Dinas Prindustrian Perdagangan Koperasi dan UKM Daerah istimewa Yogyakarta Untuk Meningkatkan Daya Saing UKM, Skripsi. Yogyakarta: Universitas Muhammadiyah Yogyakarta.

Rochman, N. 2011, Analysis of Indonesian Agroindustry Competitiveness in Nanotechnology Development Perspective Using SWOT-AHP Method. International Journal of Business and Management, 6(8), 235.

[Wati, N. K. 2014, Strategi Pengembangan Industri Pengolahan Apel Berbasis Ekonomi (Studi pada Dinas Koperasi, UKM, Perindustrian dan Perdagangan Kota Batu). Jurnal Administrasi Publik, 102-108.

Wibowo, H., Ciptomulyono, U. S., \& Singgih, M. L. 2011, Penentuan Strategi Pengembangan Sub Sektor Ekonomi Unggulan Di Kabupaten Jombang Dengan Pendekatan Methode Locatien Quotien dan Analytical Hierarchy Process (AHP).

Wulandari, J. 2009, Strategi Pengembangan Kawasan Industri Kecil Berbasis Komoditas Unggulan (studi kasus kawasan sentra industri keripik kota Bandar Lampung), Tesis. Jakarta: Universitas Indonesia. 